\title{
Mechanism for Conversion of Spirosolane Derivative into Pregnane
}

\author{
Toshihiro Nohara, ${ }^{*, a}$ Kahori OKamoto, ${ }^{a}$ Sayaka Matsushita, ${ }^{b}$ Yukio Fujiwara, ${ }^{b}$ Tsuyoshi Ikeda, ${ }^{b}$ \\ Hiroyuki MiYashita, ${ }^{b}$ Masateru OnO ${ }^{c}$ Hitoshi Yoshimitsu, ${ }^{a}$ Hisako Kansui, ${ }^{a}$ and Takehisa KuniedA ${ }^{a}$ \\ ${ }^{a}$ Faculty of Pharmaceutical Sciences, Sojo University; 4-22-1 Ikeda, Kumamoto 860-0082, Japan: ${ }^{b}$ Faculty of Medical \\ and Pharmaceutical Sciences, Kumamoto University; 5-1 Oe-honmachi, Kumamoto 862-00973, Japan: and ${ }^{c}$ School of \\ Agriculture, Tokai University; Kawayou, Minamiaso-mura, Aso-gun, Kumamoto 869-1404, Japan. \\ Received February 6, 2008; accepted April 2, 2008; published online April 21, 2008
}

Previously, we reported an interesting reaction by which esculeogenin A $[(5 \alpha, 22 S, 23 S, 25 S)-3 \beta, 23,27$-trihydroxyspirosolane], a sapogenol of tomato-saponin, esculeoside $\mathbf{A}$, was easily converted into a pregnane derivative, $5 \alpha$-pregn-16-en-3 $\beta$-ol-20-one, merely by refluxing with pyridine and water. Its chemical mechanism including air oxidation is here described.

Key words tomato; spirosolane; pregnane

Previously, we discovered a novel reaction by which a sapogenol named esculeogenin $\mathrm{A}^{1,2)}[(5 \alpha, 22 S, 23 S, 25 S)$ $3 \beta, 23,27$-trihydroxyspirosolane], of tomato-glycoside esculeoside $\mathrm{A}^{1,2)}$ was converted into a pregnane derivative, $5 \alpha$ pregna-16-ene-20-one. ${ }^{3)}$ This reaction is regarded caused by the presence of the hydroxyl group at $\mathrm{C}-23$, which would make the $\mathrm{E}$ and $\mathrm{F}$ rings fragile. Also, this reaction appears very important since it is expected that when steroidal glycosides such as spirostanol, furostanol, and spirosolane glycosides are administered orally, they would be metabolized to the hydroxylated C-23 and these intermediates would next be metabolized into pregnane derivatives showing various pharmacological bio-activities. Here, we report its reaction mechanism. ${ }^{4,5}$

Esculeoside A was refluxed with $2 \mathrm{~N} \mathrm{HCl}-\mathrm{MeOH}$ for $1.5 \mathrm{~h}$ to give the hydrolysate (1) in a yield of $38 \%$. The molecular formula of 1 was estimated as $\mathrm{C}_{33} \mathrm{H}_{55} \mathrm{NO}_{9}$ by FAB-MS. Its various 2D-NMR (FG-COSY, HMQC, HMBC) made the following assignments: The respective signals due to $\mathrm{H}_{3}-19, \mathrm{H}_{3}$ 18, $\mathrm{H}_{3}-21, \mathrm{H}-17$, Ha-26, $\mathrm{H}-20, \mathrm{Hb}-26$, and $\mathrm{H}-16$ appeared at $\delta 0.75(3 \mathrm{H}, \mathrm{s}), 1.00(3 \mathrm{H}, \mathrm{s}), 1.05(3 \mathrm{H}, \mathrm{d}, J=7.5 \mathrm{~Hz}), 1.81$ $(1 \mathrm{H}, \mathrm{d}-\mathrm{like}, J=8.2 \mathrm{~Hz}), 2.95(1 \mathrm{H}, \mathrm{d}, J=11.6 \mathrm{~Hz}), 3.00(1 \mathrm{H}, \mathrm{t}-$ like, $J=7.3 \mathrm{~Hz}), 3.23(1 \mathrm{H}, \mathrm{dd}, J=3.2,11.6 \mathrm{~Hz})$, and 4.44 $(1 \mathrm{H}, \mathrm{m})$. The signal due to one anomeric proton was also observed at $\delta 4.88(1 \mathrm{H}, \mathrm{d}, J=7.9 \mathrm{~Hz})$. The ${ }^{13} \mathrm{C}-\mathrm{NMR}$ data also suggested the existence of sapogenol C-1-27, together with one $\beta$-D-glucopyranosyl moiety $\mathrm{C}-1-6$. The HMBC between anomeric proton and C-27 indicated $\beta$-D-glucopyranosyl moiety links to the C-27 hydroxyl group. Therefore, the structure of 1 was determined to be esculeogenin A 27$O$ - $\beta$-D-glucopyranoside.

Next, a solution of compound $\mathbf{1}$ in pyridine was kept at $\mathrm{rt}$ for $3 \mathrm{~d}$ at $\mathrm{rt}$ to provide compound 2 in a $68 \%$ yield. In the ${ }^{1} \mathrm{H}-$ NMR spectrum, the signal due to $\mathrm{H}_{3}-21$ appeared at $\delta 1.51$ $(3 \mathrm{H}, \mathrm{d}, J=7.5 \mathrm{~Hz})$ and that due to $\mathrm{H}-16$ at $\delta 5.30$, both of which were lower shifted by +0.46 and $+0.86 \mathrm{ppm}$ by comparing with those of 1 . This indicated that the C-23-hydroxy group in equatorial configulation approached $\mathrm{H}_{3}-21$ and $\mathrm{H}$ 16, causing extreme lower shifts for $\mathrm{H}_{3}-21$ and $\left.\mathrm{H}-16{ }^{6}{ }^{6}\right)$ That is, the F-ring was reversed at C-22. The E-ring once opened to give enamine-imine-type intermediates, to which the 16$\mathrm{OH}$ recyclization took place as shown in Chart 2.

A solution of compound $\mathbf{2}$ in pyridine was kept at $r t$ for a further $2 \mathrm{~d}$ to afford compound 3 in a yield of $66 \%$. Compound 3 showed a singlet olefic methyl signal at $\delta 1.72$ in the ${ }^{1} \mathrm{H}-\mathrm{NMR}$ spectrum, on the other hand, the ${ }^{13} \mathrm{C}$-NMR spectrum exhibited the occurrence of one double bond at $\delta 95.7$ and 165.2 , which latter were assigned to $\mathrm{C}-20$ and $\mathrm{C}-22$ by the HMBC. Its chemical structure was represented as shown in Chart 1.

Subsequently, compound $\mathbf{3}$ was refluxed with pyridine and water $(1: 1)$ to provide compound 4 in a yield $52 \%$. The mo-
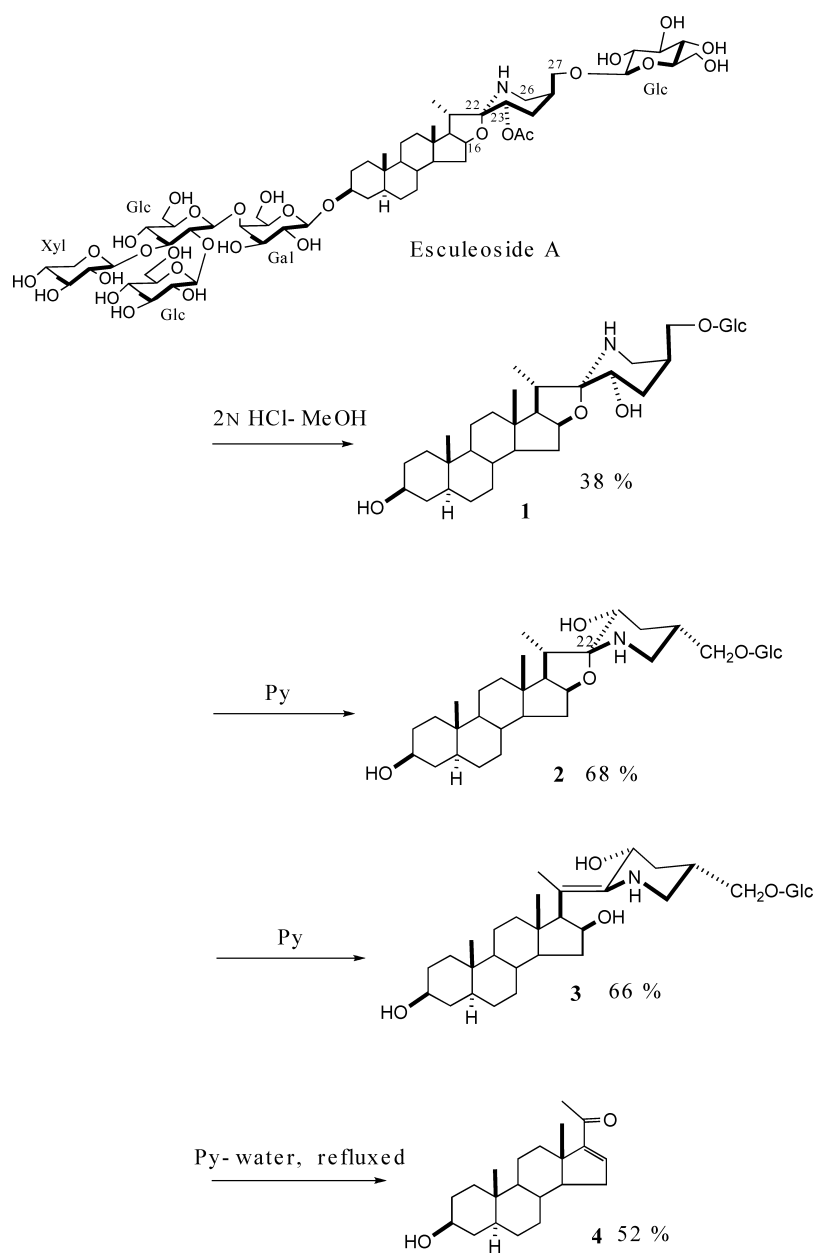

Chart 1 

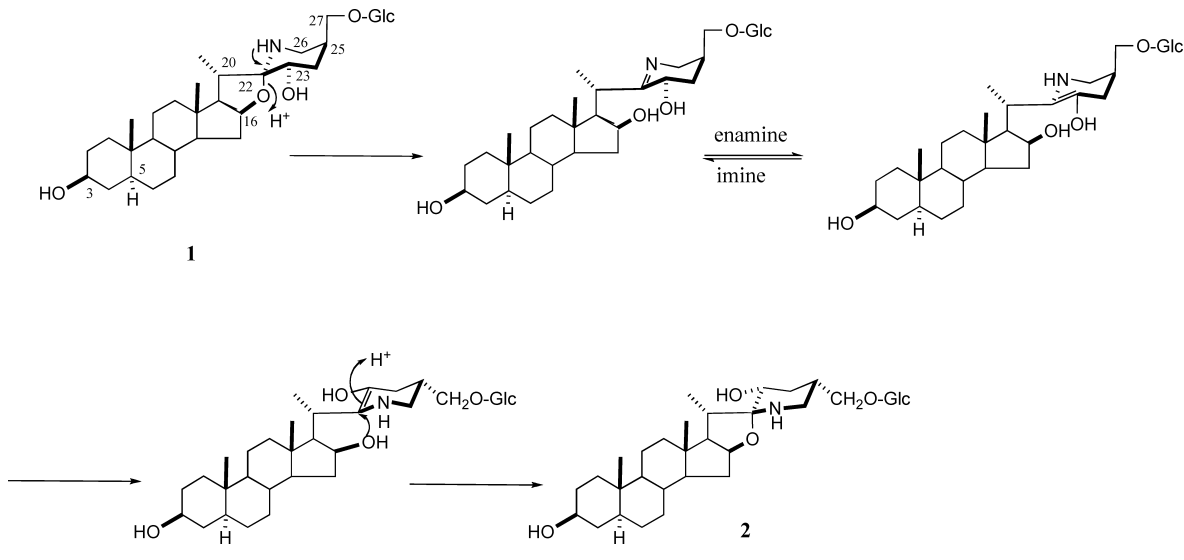

Chart 2
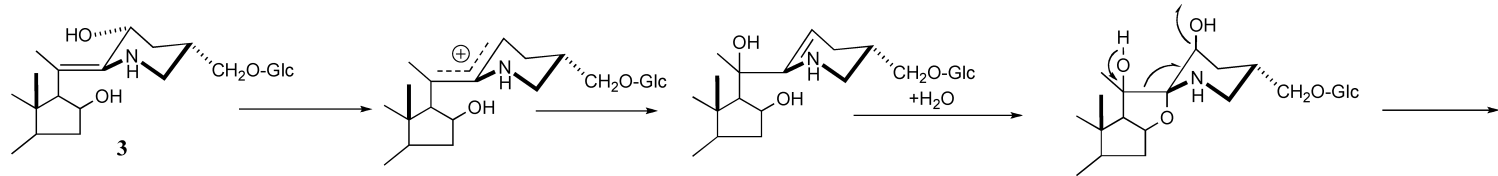

Chart 3

lecular formula was expressed as $\mathrm{C}_{21} \mathrm{H}_{32} \mathrm{O}_{2}$ by the evidence of ${ }^{13} \mathrm{C}-\mathrm{NMR}$ and EI-MS. Its ${ }^{1} \mathrm{H}-\mathrm{NMR}$ spectrum displayed the signal at $\delta 2.26$ due to $\mathrm{H}_{3}-21$ and an olefic proton signal at $\delta$ 6.62 due to $\mathrm{H}-16$. The ${ }^{13} \mathrm{C}-\mathrm{NMR}$ spectrum had 21 carbon signals in total, among which one $\alpha, \beta$-unsaturated carbonyl system was observed at $\delta 155.5,144.7$, and 196.3. Its structure was characterized as $5 \alpha$-pregn-16-en- $3 \beta$-ol-20-one, namely allopregnenolone. ${ }^{7,8)}$ This last reaction comprising a significant sensation was deduced to be as shown in Chart 3 . Opening of E-ring was followed by formation of a double bond between $\mathrm{C}-20$ and $\mathrm{C}-22$. This was followed by transformation of the double bond into C-22 and C-23, and introduction of a hydroxyl group into $\mathrm{C}-20$. To the double bond between $\mathrm{C}-22$ and $\mathrm{C}-23$, molecular $\mathrm{H}_{2} \mathrm{O}$ was added. Next, elimination of the hydroxyl group at $\mathrm{C}-23$ took place, followed by bond fission between $\mathrm{C}-20$ and $\mathrm{C}-22$ to provide compound 4 carrying a carbonyl group at C-20. Taking into consideration that this last reaction was not accelerated by introduction of oxygen and did not progress without $\mathrm{H}_{2} \mathrm{O}$, therefore, the reaction mechanism for this last stage was deduced as shown in Chart 3.

This reaction might be applied as a new synthetic pathway for production of steroidal hormone. Moreover, it might be predicted that when steroidal glycosides such as spirostanol and furostanol glycosides are administered orally, they would be metabolized to the C-23 hydroxylate and these intermediates would next be metabolized into pregnane derivatives showing various pharmacological bio-activities.

\section{Experimental}

General MS were recorded on a JEOL JMS-700. ${ }^{1} \mathrm{H}$ - and ${ }^{13} \mathrm{C}-\mathrm{NMR}$ spectra were recorded with a JEOL alpha 500 spectrometer at 500 and $125 \mathrm{MHz}$, respectively; band chemical shifts were given on a $\delta(\mathrm{ppm})$ scale with tetramethylsilane (TMS) as internal standard. Silica gel 60 (Merk, Art. 9385), Sephadex LH20 (Pharmacia Fine Chemicals), Chromatorex ODS (Fuji Silysia Chemical, Ltd.), and Diaion HP20 (Mitsubishi Chemical Industries Co., Ltd.) were used for column chromatography.

Extraction and Separation of Esculeoside A The ripe fruits ( $865 \mathrm{~g}$ ) of commercial mini tomato, Lycopersicon esculentum MiLL., were smashed with water by mixer for $5-10 \mathrm{~s}$ and filtered with paper filter to give a filtrate, which was then passed through Diaion HP20 first with water then $\mathrm{MeOH}$. The methanolc eluate was evaporated to give a residue. It was subsequently subjected to Sephadex LH20 with $95 \% \mathrm{MeOH}$ to afford fractions (432 mg) including esculeoside A.

Acid Hydrolysis of Esculeoside A A solution of esculeoside A $(420 \mathrm{mg})$ in $2 \mathrm{~N} \mathrm{HCl}-\mathrm{MeOH}(5 \mathrm{ml})$ was refluxed for $1.5 \mathrm{~h}$. After neutralization with $3 \% \mathrm{KOH}$, the mixture was concentrated, added with water $(100 \mathrm{ml})$, and passed through Diaion HP20 eluted with water then $\mathrm{MeOH}$, which was evaporated to give the residue. It was chromatographed on silica gel column chromatography with $\mathrm{CHCl}_{3}-\mathrm{MeOH}$-water $=9: 2: 0.1$ to $8: 2: 0.2$ to give compound 1 (76.6 $\mathrm{mg})$ as a major component. An amorphous powder, FAB-MS $(\mathrm{m} / \mathrm{z}) 632\left[\mathrm{C}_{33} \mathrm{H}_{55} \mathrm{NO}_{9}+\mathrm{Na}\right]^{+}$, ${ }^{1} \mathrm{H}-\mathrm{NMR}$ (in pyridine- $\left.d_{5}\right) \delta: 0.75\left(3 \mathrm{H}, \mathrm{s}, \mathrm{H}_{3}-19\right), 1.00\left(3 \mathrm{H}, \mathrm{s}, \mathrm{H}_{3}-18\right), 1.05(3 \mathrm{H}, \mathrm{d}, J=7.5 \mathrm{~Hz}$, $\left.\mathrm{H}_{3}-21\right), 1.81(1 \mathrm{H}, \mathrm{d}-\mathrm{like}, J=8.2 \mathrm{~Hz}, \mathrm{H}-17), 2.95(1 \mathrm{H}, \mathrm{d}, J=11.6 \mathrm{~Hz}, \mathrm{H} a-26)$, $3.00(1 \mathrm{H}, \mathrm{t}$-like, $J=7.3 \mathrm{~Hz}, \mathrm{H}-20), 3.23(1 \mathrm{H}, \mathrm{dd}, J=3.2,11.6 \mathrm{~Hz}, \mathrm{H} b-26)$, $4.36(1 \mathrm{H}, \mathrm{dd}, J=4.9,11.6 \mathrm{~Hz}$, glc $\mathrm{H} a-6), 4.44(1 \mathrm{H}, \mathrm{m}, \mathrm{H}-16), 4.88(1 \mathrm{H}, \mathrm{d}$, $J=7.9 \mathrm{~Hz}$, glc H-1). ${ }^{13} \mathrm{C}-\mathrm{NMR}$ (in pyridine- $d_{5}$ ) $\delta: 37.5,32.3,70.6,39.3$, $45.2,29.1,32.6,35.2,54.6,35.9,21.4,40.7,41.5,56.5,32.4,79.3,63.0$, $17.3,12.5,34.7,15.1,101.5,65.7,17.3,12.5,34.7,15.1,101.6,65.8,33.2$, $40.3,35.9,71.3$ (glucosyl C-1-6) $\delta: 105.0,75.3,78.5,71.8,78.4,62.9$.

Compound 2 A solution of compound $1(120 \mathrm{mg})$ in pyridine $(8 \mathrm{ml})$ was left to stand at $\mathrm{rt}$ for $3 \mathrm{~d}$. Thereafter, the solvent was evaporated to provide a residue, which was separated by silica gel with $\mathrm{CHCl}_{3}-\mathrm{MeOH}-$ water $=8: 2: 0.2$ to give compound $2(81.6 \mathrm{mg})$. An amorphous powder, FAB-MS $(\mathrm{m} / \mathrm{z}) 632\left[\mathrm{C}_{33} \mathrm{H}_{55} \mathrm{NO}_{9}+\mathrm{Na}\right]^{+},{ }^{1} \mathrm{H}-\mathrm{NMR}$ (in pyridine- $d_{5}$ ) $\delta: 0.75$ $\left(3 \mathrm{H}, \mathrm{s}, \mathrm{H}_{3}-19\right), 0.89\left(3 \mathrm{H}, \mathrm{s}, \mathrm{H}_{3}-18\right), 1.51\left(3 \mathrm{H}, \mathrm{d}, J=7.5 \mathrm{~Hz}, \mathrm{H}_{3}-21\right), 3.10(1 \mathrm{H}$, t-like, $J=11.5 \mathrm{~Hz}, \mathrm{Ha}-26), 3.16(1 \mathrm{H}, \mathrm{dd}, J=3.1,11.5 \mathrm{~Hz}, \mathrm{Hb}-26), 4.78(1 \mathrm{H}$, d, $J=7.9 \mathrm{~Hz}$, glc $\mathrm{H}-1), 5.30(1 \mathrm{H}, \mathrm{m}, \mathrm{H}-16) .{ }^{13} \mathrm{C}-\mathrm{NMR}$ (in pyridine- $\left.d_{5}\right) \delta$ : $37.3,32.3,70.4,39.1,45.5,28.9,32.4,35.1,54.5,35.7,21.4,40.8,40.5$, 55.7, 34.1, 82.6, 63.5, 16.6, 12.4, 45.0, 15.1, 102.2, 72.7, 27.7, 43.8, 41.0, 71.5, (glucosyl C-1—6) $\delta$ : 104.5, 74.9, 78.4, 71.7, 78.4, 62.6 .

Compound 3 A solution of compound $2(96 \mathrm{mg})$ in pyridine $(9 \mathrm{ml})$ was further kept standing at $\mathrm{rt}$ for $2 \mathrm{~d}$. The solution was then evaporated to afford a residue, which was chromatographed on silica gel with $\mathrm{CHCl}_{3}-\mathrm{MeOH}-$ water $=8: 2: 0.2$ to provide compound $3(63.3 \mathrm{mg})$. An amorphous powder, FAB-MS $(m / z) 632\left[\mathrm{C}_{33} \mathrm{H}_{55} \mathrm{NO}_{9}+\mathrm{Na}\right]^{+},{ }^{1} \mathrm{H}-\mathrm{NMR}$ (in pyridine- $\left.d_{5}\right) \delta: 0.80$ $\left(3 \mathrm{H}, \mathrm{s}, \mathrm{H}_{3}-19\right), 0.82\left(3 \mathrm{H}, \mathrm{s}, \mathrm{H}_{3}-18\right), 1.72\left(3 \mathrm{H}, \mathrm{s}, \mathrm{H}_{3}-21\right), 4.81(1 \mathrm{H}, \mathrm{d}$, $J=7.5 \mathrm{~Hz}$, glc $\mathrm{H}-1$ ). ${ }^{13} \mathrm{C}$-NMR (in pyridine- $d_{5}$ ) $\delta: 37.2,32.4,70.4,39.1$, $42.0,28.9,33.3,34.9,54.8,35.6,20.8,39.8,39.8,54.6,31.7,73.2,53.9$, $12.3,13.2,95.7,19.4,165.2,66.5,24.9,45.1,47.1,70.2$, (glucosyl C-1-6) $\delta: 104.9,75.0,78.5,71.8,78.6,62.7$.

Compound 4 After a solution of compound $3(67 \mathrm{mg})$ in pyridine $(10 \mathrm{ml})$ was refluxed for $3 \mathrm{~h}$, it was evaporated to give a residue, which was chromatographed on silica gel using $n$-hexane-acetone $=3: 1$ to provide 
compound 4 (18.1 mg), $5 \alpha$-pregn-16-en-3 $\beta$-ol-20-one, allopregnenolone Colorless needles, mp 203-205 ${ }^{\circ} \mathrm{C}$, EI-MS $(\mathrm{m} / \mathrm{z}) 316\left[\mathrm{C}_{21} \mathrm{H}_{32} \mathrm{O}_{2}\right]^{+}$, HR-EIMS $(m / z) 316.2432$ (Calcd for $\mathrm{C}_{21} \mathrm{H}_{32} \mathrm{O}_{2} 316.2402$ ), ${ }^{1} \mathrm{H}$-NMR (in pyridine$\left.d_{5}\right) \delta: 0.82\left(3 \mathrm{H}, \mathrm{s}, \mathrm{H}_{3}-19\right), 0.94\left(3 \mathrm{H}, \mathrm{s}, \mathrm{H}_{3}-18\right), 2.26\left(3 \mathrm{H}, \mathrm{s}, \mathrm{H}_{3}-21\right), 3.85$ $(1 \mathrm{H}, \mathrm{m}, \mathrm{H}-3), 6.62(1 \mathrm{H}, \mathrm{dd}, J=1.8,3.1 \mathrm{~Hz}, \mathrm{H}-16) .{ }^{13} \mathrm{C}-\mathrm{NMR}$ (in pyridine- $d_{5}$ ) $\delta: 32.5,32.2,70.6,37.3,45.5,29.1,32.3,34.0,56.6,36.0,21.4,39.3,46.6$, $55.1,35.4,144.7,155.5,16.3,12.4,196.3,30.5$.

Acknowledgements This work was supported by a Grant-in-Aid for the Takeda Science Foundation and JSPS Asian Core Program.

\section{References}

1) Fujiwara Y., Yahara S., Ikeda T., Ono M., Okawa M., Nohara T., Chem. Pharm. Bull., 51, 234-235 (2003).
2) Fujiwara Y., Takaki A., Uehara Y., Ikeda T., Okawa M., Yamauchi K., Ono M., Yoshimitsu H., Nohara T., Tetrahedron, 60, 4915-4920 (2004).

3) Yoshihara T., Nagaoka T., Sakamura S., Phytochemistry, 27, 39823984 (1988).

4) Matsushita S., Yoshizaki M., Fujiwara Y., Ikeda T., Ono M., Okawara T., Nohara T., Tetrahedron Lett., 46, 3549-3551 (2005).

5) Nohara T., Ikeda T., Fujiwara Y., Matsushita S., Noguchi E., Yoshimitsu H., Ono M., J. Nat. Med., 61, 1-13 (2007).

6) Matsushita S., Yanai Y., Fusyuku A., Ikeda T., Ono M., Nohara T., Chem. Pharm. Bull., 55, 1079-1081 (2007).

7) Sato Y., Katz A., Mosettig E., J. Am. Chem. Soc., 74, 538-539 (1952).

8) Sato H., Sakamura S., Agric. Biol. Chem., 37, 225-231 (1973). 